\title{
Experiences of a battalion medical officer in the retreat to Dunkirk: III
}

Richard Doll

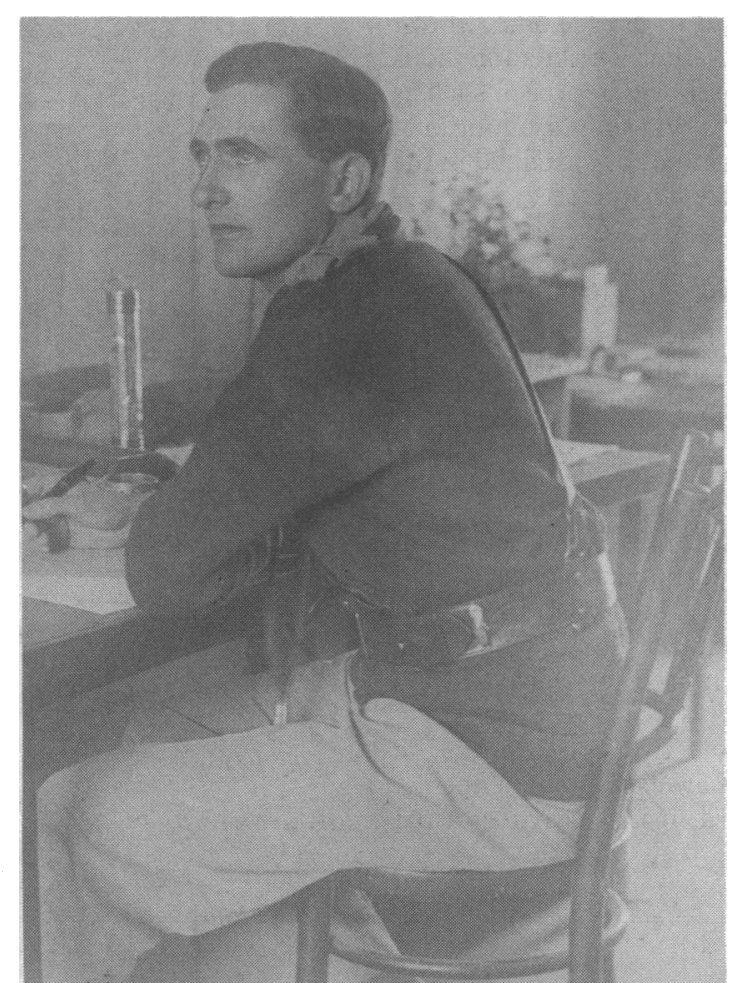

Richard Doll, Cairo, 1943

\section{Tuesday 21 May}

What a delightful day. It was rumoured that some enemy armoured fighting vehicles had been seen the other side of the Escaut, but in general we had the impression that we were out of contact and could move about in the open freely. The position was unfortunate in that our side of the river was almost entirely flat while there was a high hill, Mont St Aubert, on the German side; on the other hand, the flatness gave our men excellent fields of fire, and the Germans would have had an unpleasant time moving across the open fields. On our left front there was a small wood and some 200 yards behind that a row of five or six houses in which we had our battalion headquarters, mess, and regimental aid post. A high water tower 100 yards away made it an obvious target for shell fire so that I should not have liked to have stayed there throughout a long battle; however, there was absolutely nowhere else to go. The village was on our extreme right front, and way behind in front of a large wood was a single house to which our rear battalion headquarter's was shortly transferred; for the rest, the ground was flat, open fields.

Clinical Trial Service Unit and ICRF Cancer Study Unit, Radcliffe Infirmary, Oxford OX2 6HE

Richard Doll, FRS, honorary member and emeritus professor the cellar, which was arched and made of bricks, appeared reasonably strong. We then set about furnishing it with carpets, chairs, and as liberal a store of wine and spirits as we could collect. This last was more difficult than previously as men were not supposed to collect alcohol.

The third brigade were supposed to be on our right, but until the evening this was composed of the DWR and two companies of Royal Engineers, as the Foresters (and I think the King's Shropshire Light Infantry) had not yet turned up. They did eventually, having had an unpleasant time getting away from the Dendre; in fact when the Foresters entered Renaix the town was bedecked with flags and the mayor came out to meet them, thinking that they were Germans. We had lost contact with some $\mathbf{4 0}$ men during the retreat, but most of them turned up in the next day or two; I don't think any had become prisoners. Our total casualties so far were three, due respectively to blowing up a bridge, being shot by a sentry, and one man shooting himself in the leg with a Bren gun. Many enemy bombers flew over us in the course of the day, but left us alone for targets further back. A Lysander also flew over frequently. We became very suspicious of its activities and decided in future to fire on it if it came low enough; looking back on it there can be no doubt that it was a German plane. There was some shelling in the evening on both sides so I decided to move the mattress down on to the ground floor.

\section{Wednesday 22 May}

In the early hours of the morning an intense battle with artillery and small arms woke me up, but I had no cause to get off my bed. Towards breakfast the noise died down on our front but continued unabated on our left. We soon learnt that the enemy had. broken through the Guards about two miles away, and we changed our dispositions to face left as well as to the front, while one company was prepared to counter attack. However, we were left undisturbed, as the North Staffordshires on our left succeeded in holding the enemy and they, with the help of the 6th Gordons, who had been in reserve, were able to counter attack and re-establish the line. It later appeared that the Guards had been subjected to intense shelling and had suffered a large number of casualties; the Germans succeeded in crossing only in small numbers, but it was essential to push them back before nightfall for fear they should make a bridgehead and get their armoured fighting vehicles over during the night. The enemy also made a determined effort on our right and at one time it was rumoured that they had broken through there, but this apparently was untrue. Fortunately, I had a good book, and with the aid of some good wine I spent a happy enough day in my house, to which all were welcome for five minutes' peace and quiet. When the rations came up that evening I was very pleased to receive a case of a dozen bottles of brandy from the quartermaster, a present which I subsequently carried back to Poperinghe - though in a depleted state.

We soon found how annoying it is to be overlooked 


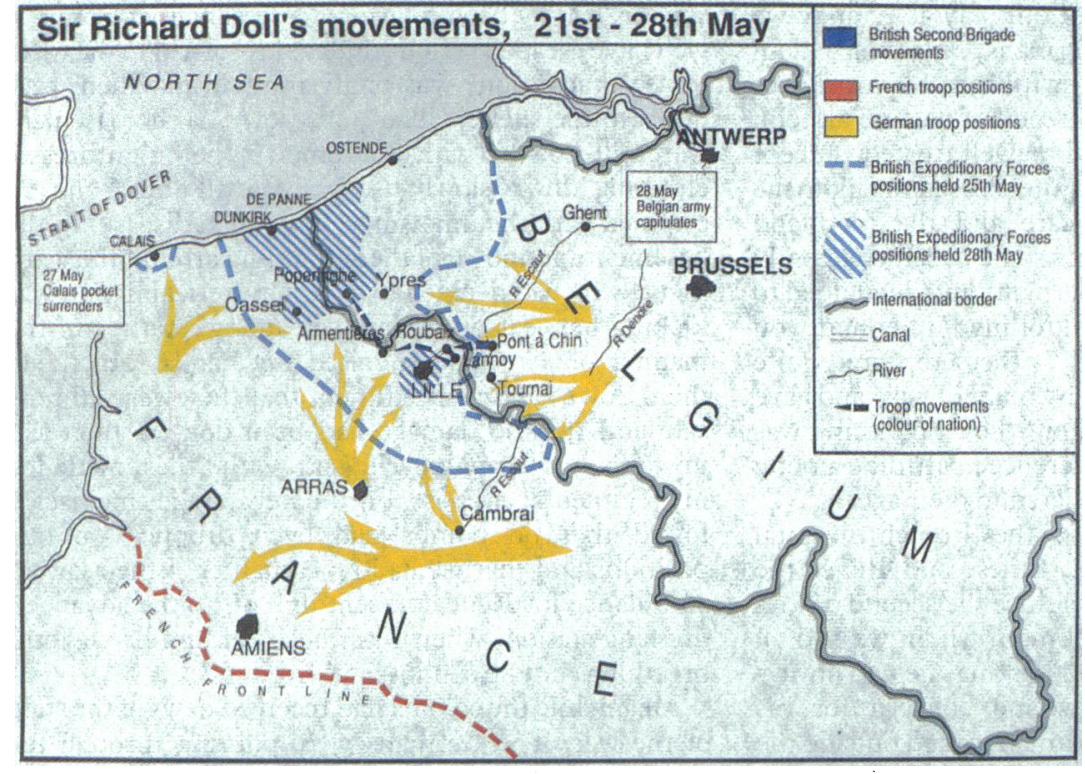

Note: British Second Brigade movements refer to movements of 2nd Brigade of 1st Division

by the enemy as most of our terrain could be swept by their machine guns. However, our houses were protected from direct view by the wood in front of us, and it was very disappointing when, after one burst, I found three or four bullet holes in my back door. We went to bed again that night well content with the day's work. The morning had evidently shown the enemy that they could not walk over our positions and where they had got through they had been quickly pushed back. Our spirits began to revive, especially when we remembered that we had our prepared line behind us; the only thing that worried us was the big break through the French lines which had caused the retreat from the Dyle. We could not understand how the Germans had been able to deploy through a gap initially no wider than 10 miles, and was there going to be no counter attack? When we heard that Arras and Cambrai had fallen it became too difficult and we had to give it up.

\section{Thursday 23 May}

After the previous day's battle the absence of shell fire was very noticeable all the morning and afternoon. However, we were not left to enjoy the peace as we had heard that we were to retire that evening to the lines in front of Roubaix, which the army had been preparing throughout the winter. We were to leave at $2200-$ that is, as it became dusk. To my horror, at about 1800 the Germans began to put down an intense mortar and artillery barrage, and we visualised a full blooded attack being delivered at just about the time we were due to leave. What would have happened if they had attacked I do not know - it would certainly have been most unpleasant; but for some reason the barrage ceased after three hours, and we were left to retire in peace. Several shells had fallen on our section posts and I had some 20 casualties during this bombardment, of whom two or three died, and some others were of course killed and were not brought to me. These were our first casualties due to enemy activity in the whole campaign, except for three men and the officer of the carrier platoon who had received small bits of shellcasing in their legs from a burst the day before. Fortunately, an ambulance had been left with me till the last moment, and I was able to get the most severely wounded away in that, packing the rest into a $30 \mathrm{cwt}$ truck which the adjutant found for me. Just before we left my driver turned up, to my great delight, and took off my now considerable store of medical equipment, mattresses, and wine. He had been ordered to stay with
B echelon ever since we had first reached the Dyle, but I had at last succeeded in persuading the colonel that it was essential to keep him with me.

\section{Friday 24 May}

After a short and really very pleasant march we reached Lannoy at dawn. Our position was some $10 \mathrm{~m}$ miles nearer the coast than the one we had prepared during the winter: there was practically no concrete, but there were excellent fire trenches and, in most $\stackrel{0}{\rightarrow}$ parts, fairly adequate communicating trenches. In $\bar{C}$ front of us there was an anti-tank ditch and a few lines 흠 of wire. We were spread over a front of 200 yards in the $\frac{5}{7}$ form of a salient with the Guards on our left and the $\stackrel{\mathbb{Q}}{\Omega}$ North Staffordshires on our right. Our headquarters क was sited in a fine, modern chateau at the midpoint of the base of the salient, and our reserve company was located opposite. Behind our line the town of Lannoy $\overrightarrow{\vec{\omega}}$ spread backwards into the outskirts of Roubaix. We $\stackrel{\circ}{\circ}$ spent the day in great comfort in the chateau, in the $\frac{\text { O }}{3}$ basement of which I had established my regimental aid post, having taken a few hours' sleep immediately on arrival. It was quite obvious that the whole building o would collapse the first time a shell landed anywhere $\omega$ near it; in fact, the walls shook visibly when our own or guns fired off some distance away, so it was not $\vec{\omega}$ surprising that we were soon ordered to change our $\triangle$ headquarters. After dinner it was decided to move $\frac{\mathrm{S}}{\mathrm{T}}$ back almost to the other side of Lannoy, to where $\vec{\bullet}$ a large number of new flats had been built, and to establish headquarters and, incidentally, the regimental aid post, in a large modern school built of reinforced concrete. I chose a big schoolroom as far $\notin$ away as possible from the executive officers and the mess, with a separate entrance to the street. Here I laid out my mattresses, and my staff and I rapidly made ourselves comfortable and went to sleep.

\section{Saturday 25 May}

A delightful and peaceful day. The Germans apparently had not followed us with more than a few $\supset$ mobile troops, and several of these our outposts succeeded in capturing. As my regimental aid post was some two miles behind the foremost part of the line I established a relay post in the town half way back. For the rest I had my hair cut and lived the life of a 3 gentleman. In the evening I visited a large French civil hospital about 10 minutes' walk away from our $\frac{0}{3}$ headquarters and arranged to visit it the next day in case my assistance was required. The hospital, of some $\frac{3}{7}$ 500 beds, was run by nuns; two surgeons were still o working there, but otherwise the medical staff had $\supset$ either been called up or had evacuated themselves with the approach of the Germans. The town itself was fairly $N$ full, many having refused to be evacuated and others N having been turned back on their way south.

\section{Sunday 26 May}

This was another peaceful day but was marred by an unfortunate accident towards evening. At midday it $\bar{O}$ had been arranged that A company should attack a $\stackrel{\mathbb{D}}{\circ}$ position that had been observed to be an enemy $\overrightarrow{\mathbb{D}}$ observation point; all arms were cooperating in the $\frac{\varrho}{\sigma}$ attack, and it was feared there might be a lot of casualties. I established an advanced regimental aid 8 post at forward headquarters, but as it turned out I was not needed except to deal with three or four Germans

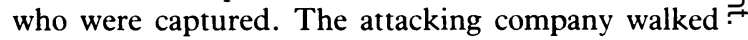
out from our lines; saw half a dozen Germans, two of whom they shot while the rest surrendered; advanced to the post in question; and then returned without being interfered with in any way. 
Altogether, in the course of our stay at Lannoy we captured about a dozen Germans, most of whom passed through my hands with greater or lesser injuries. None appeared frightened of us, and all took it for granted that they would be well treated. Except for one man, they all seemed quite pleased to talk to me and were grateful for my care and the food and cigarettes we gave them. While some became violently. emotional at the mention of Germany and demanded to be sent back, "But I must fight for my Fatherland, you must not send me to England," others appeared quite uninterested in the war from any point of view and gave the impression that as "arbeiter" the whole thing was no concern of theirs. This difference in attitude among the men I saw seemed to be related to their age.

At 1800 I went down to the French hospital accompanied by my batman, Stiles, and René, the interpreter we had had with us since the second day on the Dyle. He was a delightful man, whom we had all got very fond of: tall and good looking, he was always cheerful and seemed to have no concern for his personal safety. He and my batman waited outside the ward joking with a couple of nurses while I went inside to see the patients. Presently, we heard the sound of planes high above us and then suddenly, with an appalling shriek, a bomb fell by the side of the ward, to be followed by another, and a third. At the first sound of the falling bomb I had seized my steel helmet and thrown myself down in the middle of the room. The floor was covered with splinters of glass and the air filled with the screams of women, most of whom had one or more cuts on the hands or faces. In the corridor between two wards I found a mass of nuns, maids, and patients kneeling on the floor and crying out to be told what to do. I told them to go down to the shelter at the end of the ward and tried to explain that the attack was all over, when Stiles rushed in and said that René had been hit. I ran to the entrance of the ward and found him lying down in a pool of blood with his brain protruding from the top of his head-but still breathing. I bandaged his head with my shell dressing and with the aid of a very calm and pleasant nurse moved him into a side room. One bomb had dropped just at the entrance to the ward where René and Stiles were talking to the nurses - they had stood back to let the nurses get in first on hearing the whine of the bomb, and René had been caught just as he left for

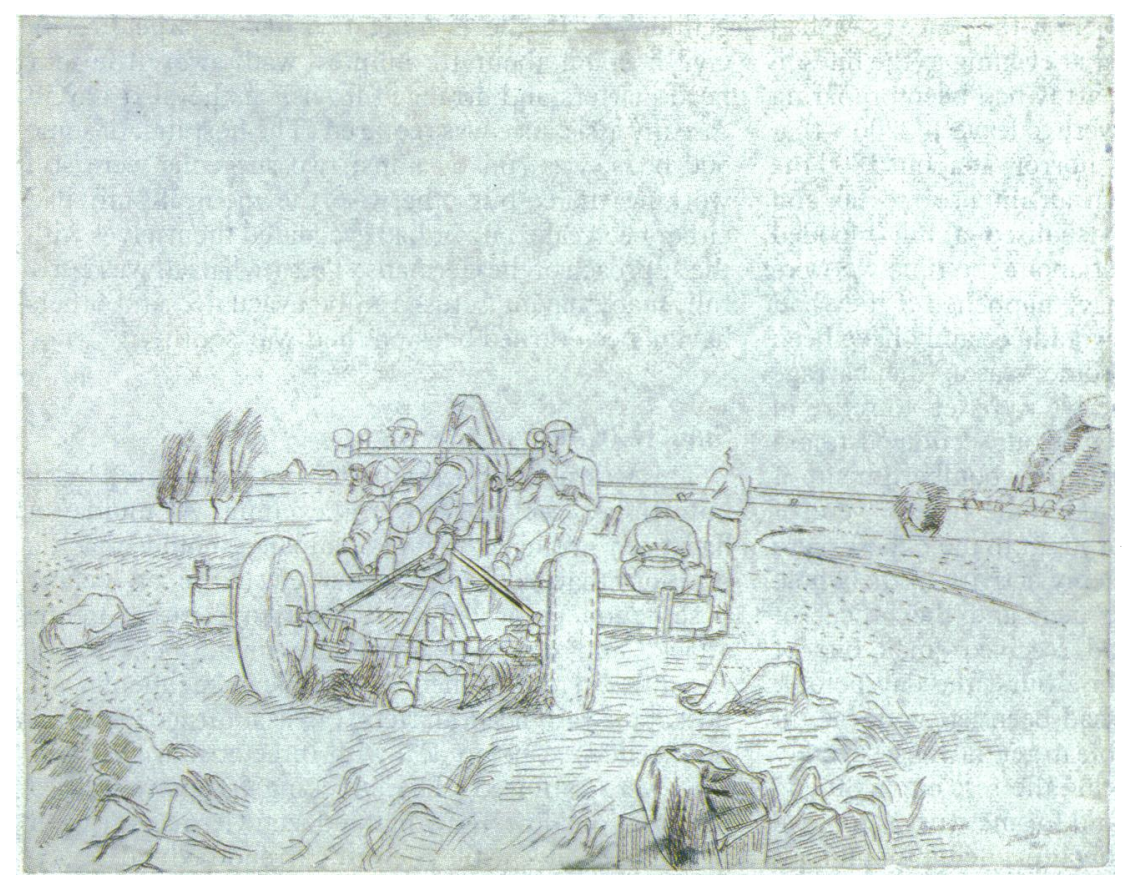

"An anti-aircraft Gun at Armentières" by Edward Bawden. Reproduced courtesy of the trustees, Imperial War Museum shelter; had he been wearing his steel helmet he might well have escaped serious injury. I returned to the ward to see that no one was badly injured and then went down to the shelter. The steps down to the basement were still crowded with old women in their nightdresses climbing down slowly, several on all fours and all crippled with rheumatism or some such disease. In the basement I found 30 of them standing around the ward sister, who had decided to have a hysterical fit and was kicking her legs about and screaming. Rather in the manner of a prophet I raised my hands, quietened them down, and assured them that they were all now safe and that no damage had been done. I then ran upstairs, got to my bicycle, and, with Stiles, made for my regimental aid post. Fortunately, on getting back I found that no bombs had been dropped on our positions and that we had no casualties. I then got an ambulance for René and sent him off to the advanced dressing station; when I last heard of him he was still breathing, but he cannot have lived.

Meanwhile the colonel had received news of the state of the war. The Germans were pouring through the now wide gap between us and the French and had turned out to the coast behind us, had reached Abbeville to the south and Boulogne and Calais to the north. There was now no hope of counter attacking them, and the decision had been taken for the whole British Expeditionary Force to withdraw through the only port left open to us at Dunkirk. As we subsequently learnt, the position had been made worse by the collapse of the Belgian armies on our left. We were to stay at Lannoy till the next day, when we were to withdraw in the evening. Serious though the situation obviously was, I at least felt a certain exhilaration. For one thing we were no longer in the dark as to what was happening, and we had some future to look forward to other than everlastingly sitting in entrenched positions at the mercy of German aeroplanes. In any case, very few of us had ever had much hopes of victory from the first moment of seeing the Belgian troops pour back over the Dyle as we moved up into position, hopes which faded practically to nothing when we were forced to withdraw from the Escaut and heard of the capture of Arras behind us.

\section{Monday 27 May}

Once again there was no enemy activity: it was obvious that the main body of the troops that had been following us had been sent to some other part of the front so that, had the general position allowed, we could probably have gone forward over much of the ground we had been retreating over.

At 1800 we were called to a conference. The news was very depressing. The Germans had reached Ypres on the north and Cassel on the south; there was therefore a gap of eight miles through which the entire army had to pass, and only one road ran through it. At Lannoy we were some 32 miles to the east of the gap, a position which we had to deny to the enemy till 2200 before we could leave; we then had to make our way to the west of Armentières during the night on foot or, if transport was available, by means of troop carriers. On arrival there we should take up our positions facing in whatever direction the enemy first came from, and then, when conditions permitted, we could continue on through the gap to Dunkirk. Not, evidently, a very bright prospect.

To my great relief the advanced dressing station detailed an ambulance to travel with us under my command as it was uncertain when we should next make contact with a field ambulance. As it turned out, I never again saw a field ambulance from our division till we were back in England.

We left at dusk in surprisingly good spirits. It was a 


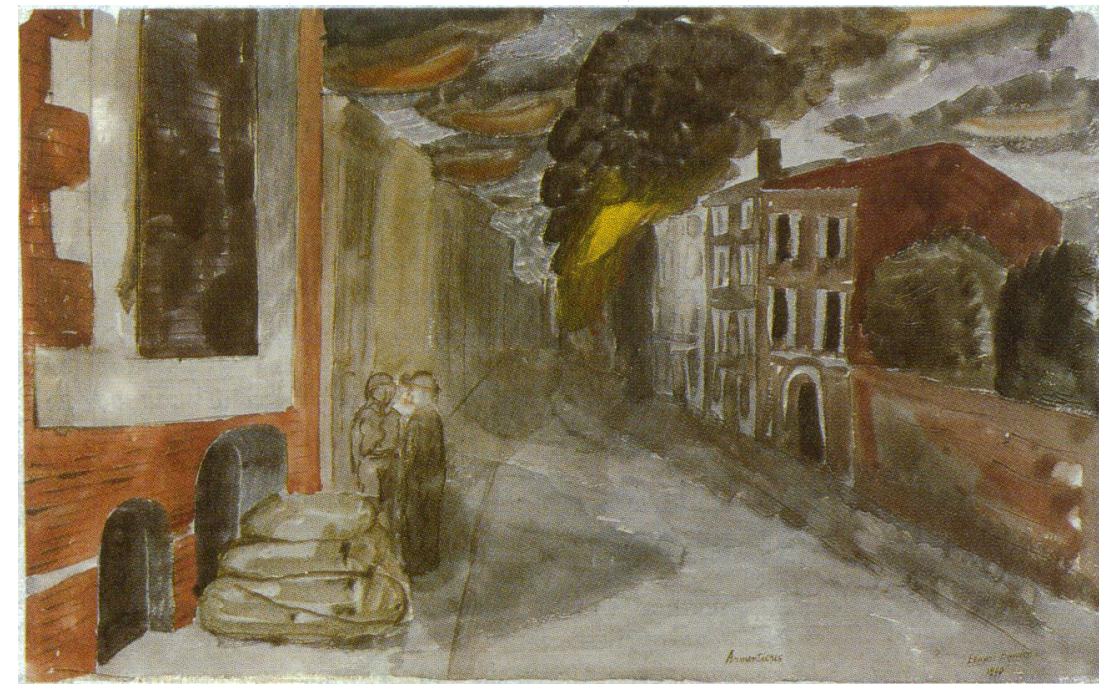

“Armentières After Bombing, May 1940" by Edward Bawden. Reproduced courtesy of the trustees, Imperial War Museum nasty situation certainly, but if we could once get through the gap we thought we were as good as home, for surely the RAF, having but one spot to protect, must have control of the air. We were to be sadly disillusioned. I, like many of the men, had got hold of a bicycle, and we set off on these for there was no knowing how far we might have to go. Carney (my medical orderly) and I rode up and down the column talking for a while to Captain Leschalles in command of D company, then on to Willy Anderson at the front of headquarters, and then dismounted for a while to march with my friends among the men. We proceeded like this for perhaps eight miles till we crossed a canal between Roubaix and Lille, where we were to wait till the Gordons had gone through. During these repeated withdrawals I always found that it was these waiting periods that got on my nerves; so long as I was marching it was not difficult to keep cheerful, but even a five minute wait seemed to be half an hour, and it was impossible not to think of this eight mile gap still 25 odd miles away from us. More than this there was the horror of daylight, for with the coming of dawn we could be certain that the German planes would also arrive. After about an hour the colonel arrived and with him the brigadier. The Gordons were now some two hours late, and it was decided that we must go on without them. Their lateness was our gain for we soon came to the troop carriers which had been meant for them, got in, and continued on our way at a better speed.

I travelled in my truck and carried Carney and Stiles and two bicycles on the back in addition to the equipment I had been collecting, which by this time largely consisted of brandy, food, and blankets.

\section{Tuesday 28 May}

We travelled on throughout the night; sometimes at $20 \mathrm{mph}$, sometimes stopped altogether for half an hour in a seemingly endless block of traffic. On all sides of us immense fires lit up the darkness where petrol dumps and other supplies had been set on fire before leaving. As we approached Armentières the flash of artillery added to the brightness. The guns seemed to be in action on all sides of us, and it seemed that we were being carried into action rather than out of it. As dawn came we found ourselves some six miles beyond Armentières in an apparently hopeless confusion. All traffic had come to a stop. Trying to get past the block, trucks from all units had piled themselves up in two continuous columns while a column of Belgian troops was trying to move in the opposite direction. A few shells passed overhead and fell beyond us and then, from behind us, six Messerschmidts appeared and performed acrobatics overhead as if to express their joy at the fate which would overtake us when they reported our position to the bomber squadrons.

I wandered along the column and eventually found the second in command. He told me that the plans had been altered and we were to carry on as far as Poperinghe-if once we could get moving. About 0700 we got moving again as a result of drastic action on the part of the brigadier and our colonel, who had held up the oncoming Belgians with revolvers and forced them to let us through. Gradually the column thinned out and speeded up. We passed through several villages that had suffered severe bombardments the day before, but wherever the road had been hit (which was very seldom) the Engineers had succeeded in making it passable again.

Presently the column halted and one company debussed, and the column proceeded to follow it at marching pace. After about 20 minutes a Royal Army Service Corps driver rode up and told me that the column was now tightly packed for two miles back and asked if he could bring his trucks past if we were to continue at this speed. I, however, decided to take the law in my own hands and sent him up to the marching troops to pass on the order for them to embus again: I imagined they would be so glad to receive it they would not question who it came from, and so it proved. Then, getting back into the truck, I led the column on to Poperinghe at a good pace.

On the outskirts of Poperinghe I found the colonel, and once more we got out and took up a defensive position on each side of the road while the cooks made tea and prepared what sort of a meal they were able to. At 0900 the German bombers appeared. Thirty of them came over and for the next half an hour they flew over Poperinghe as they willed. They dived, they stunted, and they bombed. The light anti-aircraft guns that were always with us let fly at them, as did the Brens, when the planes came low enough. One plane was brought down, but it was small consolation. I never saw the damage they did to Poperinghe, but from what I have heard and the number of bombs they dropped, it must have been severe. From then on there was nearly always one plane or more in the air but there were no more heavy raids that morning. I spent that half hour in the bottom of a ditch beneath some trees with 20 others; I had been a little quicker than my batman (a considerable feat) so that fortunately he was on top of me; this, however, did not prevent me from gripping my tube of morphine tablets throughout the raid. I can imagine nothing more infuriating for a doctor than to be hit and not to be able to get at his morphine; consequently, I made it my habit to carry it in my hand whenever a big raid started.

By 1400 the whole battalion had been collected, including B company, which, having done the rear guard at Lannoy, had found all the transport filled and gone and had had to march the whole 33 miles.

We moved from our crossroads to a brickworks near Poperinghe and took up positions facing east, south, and west. We were to stay at Poperinghe and act as rear guard and hold the Germans off from whichever direction they came for as long as possible. Meanwhile, troops continued to pour down the road on their way to the coast. All day they passed through in a continual stream, British and French of all arms, on foot, by car, in tanks, or on horses. Soon one road out of Poperinghe became inextricably blocked, and all had to pass through the centre of the desolated town. The clouds came up and it began to rain as heavily as I have ever known it; to the mens' fatigue and lack of food was now added the discomfort of being drenched-but on the other hand the clouds held off the planes.

I chose for my regimental aid post a house with a 


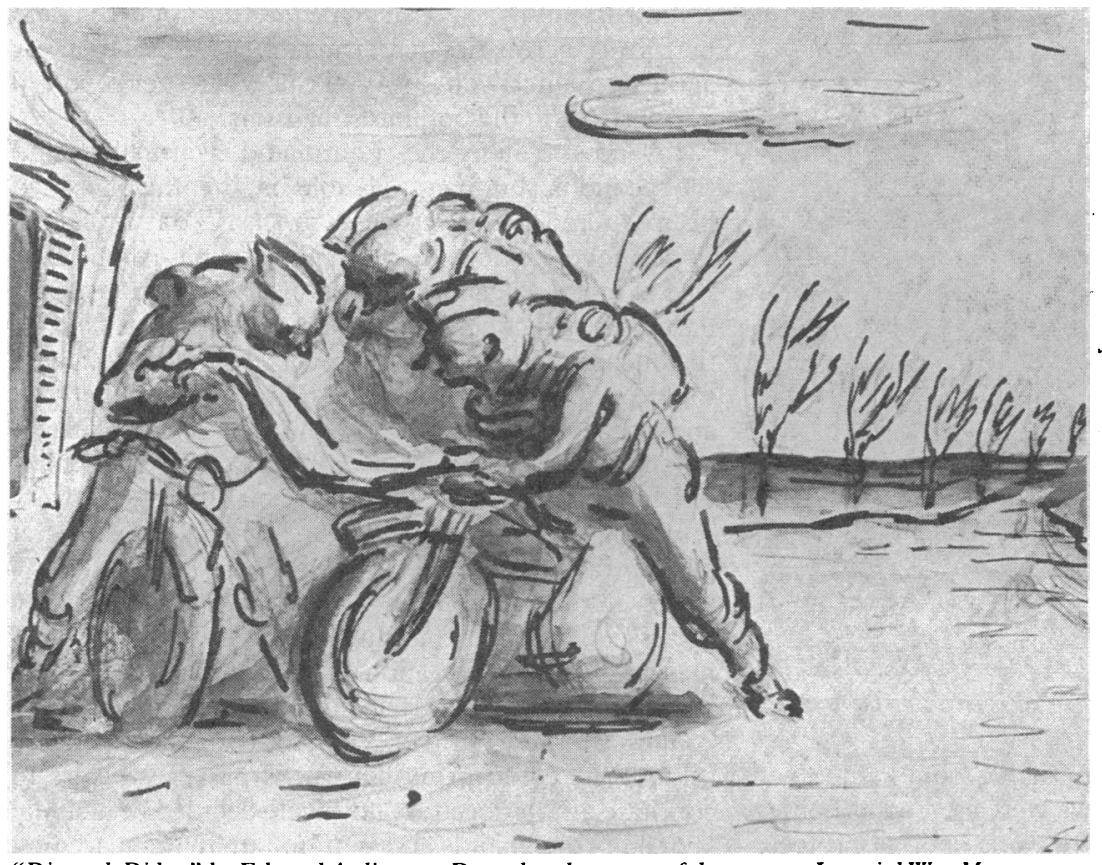

"Dispatch Riders" by Edward Ardizzone. Reproduced courtesy of the trustees, Imperial War Museum

small cellar some 100 yards behind the brickworks, where we settled down to dispel the gloom of apparently certain destruction with the wine and food that Carney had brought from Lannoy. Our landlady was a Flemish speaking woman with memories of the English in the last war. Her English was marvellous, consisting solely and perfectly of such phrases as "First today," on receiving a glass of brandy, "That's the stuff to give them," on being given some sugar, and, more expressively, "Oh the -.- .-. sergeant major!" Presently we had forgotten our troubles and for the next few hours kept open house in a hilarious fashion for whoever was able to steal five minutes off from the rain or his position.

At 2000 we were called to a conference. The last troops had passed through and we were to leave in one and a half hours. All transport was to be destroyed, and we were to march back to the concentration area around Dunkirk. As we were talking some armoured cars appeared on a road to our right, and for a few minutes we thought we had been caught, until we realised that they were French. I returned to my house and gave all my belongings to the Flemish woman, while Stansfield (my driver) set about destroying the truck. Stansfield had for the first time to my knowledge taken a little too much to drink, and it was more than he could bear to destroy the car which he had tended so lovingly for eight months. At last I persuaded him he must do it, but not before he had shed many tears. I doubt if any other car was so completely destroyed as mine.

We left at dusk with bated breath, for this time it seemed that we had done the impossible and were leaving the enemy for good. We marched, or rather staggered, down the railway line. Any civilians we met had perforce to come along with us, for how were we to tell that they would not immediately inform the Germans of our line of retreat? Guns flared to our left, but to the right there was an ominous quiet. As we learnt later, the German outposts had reached the line down which we were retreating, a fact which Gerrard, one of my stretcher bearers soon found when he went to sleep during a five minute halt. He woke to find himself a prisoner; but one hour later a stray shell killed three of his escort, and in the ensuing confusion he broke away and got back to the British lines.

Several times I went to sleep on the march, waking only when the man in front stopped and I banged into him. After three hours we were stopped by two Belgian soldiers, who told us that the bridge ahead was uncrossable and we must branch off onto the road. On leaving the railway we soon found ourselves wending our way through a long stream of traffic which had become completely blocked. On reaching the next town we turned off again to try to find the railway line we had deserted the other side of the river.

Part IV will appear next week

\section{ANY QUESTIONS}

A woman in her 50s has familial hyperlipidaemia and has been advised to start hormone replacement therapy. She tolerates transdermal oestradiol well but it has not been possible to find a progestogen preparation which suits her. She has headaches and considerable fluid retention and irritability during the progestogen phase of the treatment. What would be the best regimen to recommend, and would a progestogen course only in alternate months be satisfactory?

Postmenopausal administration of natural oestrogen by mouth is effective in lowering concentrations of low density lipoprotein cholesterol and increasing those of high density lipoprotein cholesterol, and this has been shown to reduce the risk of coronary artery disease. Transdermal and subcutaneous oestrogen preparations, however, lack this effect, which is mediated by first pass metabolism in the liver. Progestogens with significant androgenic properties have opposite effects on lipid metabolism, which clearly complicates selection of the ideal hormone replacement therapy for this patient. None of the oral progestational agents with minimal androgenic effects (medroxyprogesterone acetate, dydrogesterone, gestodene, desogestrel) is available in a formulated combined preparation, and gestodene and desogestrel are found only in oral contraceptives.

Treatment strategies to consider would therefore include continuous oral natural oestrogen with dydrogesterone or medroxyprogesterone acetate for 12 days each calendar month; continuous oral natural oestrogen with annual or biennial endometrial sampling. It seems unlikely that alternate month progestogen therapy of a duration of at least 12 days would allow significant endometrial hyperplasia, though direct evidence for this is lacking. -D H A REDFORD, consultant gynaecologist, Shrewsbury
Nikkila EA, Tikkanen MJ, Kuusi T. Gonadal hormones, lipoprotein metabolism and coronary heart disease. In: Oliver MF, Vedin A, Wilhelmsson C, eds. Myocardial infarction in women. Edinburgh: Churchill Livingstone, 1986:34-43.

Bush TL, Barrett-Connor E, Cowan LD, et al. Cardiovascular mortality and non-contraceptive use of estrogen in women. Results from the lipid research clinics program follow-up study. Circulation 1987;75:1102-9.

Are low alcohol or alcohol free drinks contraindicated for patients taking antidepressant drugs?

Antidepressants, particularly the older tricyclic compounds such as amitriptyline and imipramine, interact with alcohol in two ways. The sedative effects of the antidepressant are combined with those of alcohol by simple addition and the absorption and metabolism of the drug are altered by the presence of alcohol.' But the adverse effects on performance are detected only when about $30 \mathrm{~g}$ (one to two pints) of alcohol have been consumed. Low alcohol lagers usually contain between $0.5 \%$ and $1 \%$ of alcohol by volume so that at least five pints would need to be consumed to produce a measurable interaction with antidepressants. Some low alcohol wines contain $0.3 \%$ of alcohol and in normal quantities would rarely produce interactions with antidepressants. Some other wines and lagers are described as non-alcoholic but contain a small amount of alcohol (around $0.05 \%$ ), which is of no significance for drug interaction. There are no additional substances such as biogenic amines in these low alcohol drinks that interact with antidepressants; most are made in the same way as the alcohol rich equivalent drink and the alcohol content reduced later.

In general, therefore, it is safe to take antidepressants with low alcohol drinks but caution must be exercised if large volumes are consumed.PETER TYRER, senior lecturer in psychiatry, London

1 Dorian P, Sellers EM, Reed KI, et al. Amitriptyline and ethanol: pharmacokinetic and pharmacodynamic interaction. Eur $\mathcal{F}$ Clin Pharmacol 1983;25:325-31 